\title{
HUBUNGAN WAWASAN KEBANGSAAN TERHADAP PRESTASI MAHASISWA PGSD DENGAN MOTIVASI SEBAGAI VARIABEL MODERATINGNYA (STUDI PADA PRODI PGSD DI JAWA TIMUR)
}

\author{
Putri Mahanani ${ }^{1 *}$ \\ Muchtar $^{1}$ \\ Siti Umayaroh ${ }^{1}$ \\ M.Imron Rosyadi ${ }^{1}$ \\ Iva Sugiarti ${ }^{2}$ \\ Mohammad Resnanda Anugerah ${ }^{1}$ \\ Ike Yuli Kurniawati ${ }^{1}$ \\ Christianto Saputro ${ }^{1}$ \\ ${ }^{1}$ Pendidikan Guru Sekolah Dasar, Jurusan KSDP, Fakultas Ilmu Pendidikan, Universitas Negeri Malang \\ ${ }^{2}$ SD Modern Al Rifa'i Gondanglegi \\ ${ }^{1} \mathrm{Jl}$. Semarang No.5, Malang, Indonesia \\ ${ }^{2} \mathrm{Jl}$. Raya Ketawang No.2, Kec. Gondanglegi, Malang, Indonesia \\ *email: putri.mahanani.fip@um.ac.id
}

Artikel diterima: 28 Januari 2020; disetujui: 31 Mei 2020

\begin{abstract}
This study aims to provide empirical evidence about the influence of national insight and motivation on the relationship between national insight on the achievements of PGSD students. The design used in this study is quantitative research. The research instrument is a questionnaire. The research done in East Java, Malang and Jember. There were 432 respondents who were spread from state and private universities in East Java. Based on the data analysis, it was found that the students' knowledge related to national outlook did not affect the achievements of PGSD students. But motivation has been proven to influence the relationship between national insight and PGSD student achievement. The results showed that the existence of motivation (moderating variable) would be able to strengthen the relationship of national insight to student achievement.
\end{abstract}

Keywords: national insight; Java; PGSD; motivation; moderating variable.

\begin{abstract}
Abstrak: Penelitian ini bertujuan untuk memberikan bukti empiris mengenai pengaruh wawasan kebangsaan serta motivasi terhadap hubungan antara wawasan kebangsaan dengan prestasi mahasiswa PGSD. Rancangan penelitian menggunakan penelitian kuantitatif. Instrument penelitian berupa angket. Penelitian dilakukan di Jawa Timur, yaitu Malang dan Jember. Terdapat 432 responden yang tersebar di perguruan tinggi negeri maupun swasta di Jawa Timur. Berdasarkan hasil analisis data, didapatkan hasil bahwa pengetahuan mahasiswa terkait wawasan kebangsaan tidak memengaruhi prestasi mahasiswa PGSD. Namun motivasi terbukti memengaruhi hubungan antara wawasan kebangsaan dan prestasi mahasiswa PGSD. Hasil penelitian menunjukkan bahwa adanya motivasi (variabel moderating) akan dapat memperkuat hubungan wawasan kebangsaan terhadap prestasi mahasiswa.
\end{abstract}

Kata kunci: wawasan kebangsaan, Jawa, PGSD, motivasi, variabel moderating. 
Kondisi abad XXI memberikan peluang besar sekaligus kompetensi yang ketat bagi bangsabangsa di dunia dalam berinteraksi untuk membuat bangsanya menjadi lebih bermakna diantara yang lainnya. Tentu persaingan yang ada memerlukan ketangguhan dan keuletan dalam menghadapinya (Mahanani, 2019). Untuk itu, dengan wawasan kebangsaan yang kuat, negara ini akan mampu bertahan, tak akan disisihkan maupun tersisihkan dalam persaingan dunia di abad XXI.

Pendidikan merupakan salah satu upaya untuk membekali generasi penerus bangsa agar mampu menghadapi dan menjalani kehidupan kedepannya. Pendidikan, tak terkecuali lingkup perguruan tinggi, diharapkan dapat membentuk sosok pribadi yang tangguh, mandiri, kerja keras, gigih, serta prestatif agar terbiasa menghadapi persaingan yang ketat, mampu membaca peluang, juga memanfaatkan fasilitas yang tersedia dalam kehidupan global.

Penelitian Sundawa (2017) mengemukakan bahwa wawasan kebangsaan sangat diperlukan oleh mahasiswa sebagai generasi penerus bangsa yang dapat diberikan melalui seluruh mata kuliah yang ada. Hal ini dapat mengembangkan karakter mahasiswa berwawasan kebangsaan, khususnya pada mata kuliah rumpun sosial seperti IPS dan PKn. Hasil penelitian Sofyan \& Sundawa (2015) juga mengungkapkan bahwa wawasan kebangsaan erat kaitannya dengan semangat nasionalisme yang salah satunya diperngaruhi oleh mata kuliah PKn. Semangat kebangsaan yang dimaksud yaitu semangat kebersamaan untuk membangun masa depan yang lebih sejahtera bagi seluruh warga negara Indonesia, dengan tidak membedakan perbedaan yang ada, seperti perbedaan suku, agama, ras, warna kulit, dan gender.

Dengan semangat yang tinggi akan meningkatkan motivasi mahasiswa dalam meningkatkan kualitas diri dan mengembangkan potensinya, terutama di bangku perkuliahan. Hasil penelitian yang dilakukan oleh Sari (2018) mengungkapkan bahwa motivasi mahasiswa dalam mengikuti perkuliahan merupakan dorongan dari diri mahasiswa untuk mengikuti perkuliahan sesuai dengan keingingan, kehendak sendiri, dengan mampu melihat minat, bakat, serta kemampuan mereka untuk merencanakan masa depan. Sementara itu hasil penelitian Nurhidayah (2018) menunjukkan bahwa minat belajar dan dukungan orang tua berpengaruh tinggi pada motivasi belajar mahasiswa. Motivasi mahasiswa akan berpengaruh pada prestasinya. Hal ini diungkapkan oleh Siregar (2017) yang menyatakan bahwa terdapat hubungan yang positif antara motivasi akademik dengan prestasi akademik mahasiswa.

Beberapa unsur yang memengaruhi motivasi dalam belajar menurut Dimyati \& Mudjiono (2010), yaitu (1) cita-cita dan aspirasi sebagai wujud aktualisasi diri; (2) kemampuan untuk melaksanakan tugas-tugas perkembangan; (3) kondisi jasmani dan rohani, untuk memusatkan perhatian dalam belajar; dan (4) kondisi lingkungan, lingkungan yang sehat akan meningkatkan semangat motivasi belajar yang lebih kuat. Motivasi berfungsi sebagai pendorong usaha dan 
pencapaian prestasi, dengan motivasi belajar yang baik akan menunjukkan hasil yang baik untuk mencapai prestasi yang diimpikan (Mardianto, 2012). Motivasi juga dapat menjadi suatu variabel moderating untuk meningkatkan kecerdasan, seperti kecerdasan emosional, kecerdasan intelektual, serta kecerdasan spiritual dalam pemahaman mahasiswa (Nuraini, 2017).

Tujuan penelitian ini yaitu untuk (1) memberikan bukti empiris mengenai pengaruh wawasan kebangsaan terhadap prestasi mahasiswa PGSD; dan (2) memberikan bukti empiris mengenai pengaruh motivasi terhadap hubungan antara wawasan kebangsaan dengan prestasi mahasiswa PGSD.

\section{METODE}

Penelitian ini menggunakan pendekatan kuantitatif. Menurut Sudaryono, dkk. (2013) penelitian kuantitatif bertujuan mencari hubungan dan menjelaskan fakta-fakta sosial yang terukur. Penelitian menggunakan jenis deskriptif. Sudaryono, dkk. (2013) mengungkapkan bahwa penelitian deskrptif ditujukan untuk mendeskripsikan fenomena-fenomena dengan apa adanya. Pada penelitian ini peneliti tidak memberikan perlakuan tertentu terhadap variabel penelitian, sehingga berjalan seperti apa adanya, yang kemudian digambarkan secara deskripsi.

Populasi dalam penelitian ini ialah mahasiswa program studi Pendidikan Guru Sekolah Dasar (PGSD) se-Jawa Timur. Sampel dalam penelitian diambil dengan teknik purposive random sampling, yaitu peneliti menentukan sampel berdasarkan tujuan tertentu, dengan syarat tertentu pula yaitu didasarkan atas ciri-ciri atau karakteristik pokok populasi. Sampel benar-benar merupakan subjek yang paling banyak mengandung karakteristik populasi yang dapat diketahui dari studi pendahuluan (Arikunto, 2013; Sugiyono, 2015).

Sampel penelitian yang dipilih pada penelitian ini adalah mahasiswa yang menempuh Semester 3 pada program studi PGSD, dengan ketentuan 30\% dari setiap populasi mahasiswa PGSD di suatu universitas. Karakteristik subjek dalam penelitian ini ialah laki-laki dan perempuan, serta mahasiswa aktif pada program studi PGSD yang sedang menempuh Semester 3 pada tahun ajaran 2019/2020.

Teknik pengumpulan data dan instrumen penelitian menggunakan angket. Angket berisi seperangkat pertanyaan atau pernyataan tertulis kepada responden. Metode ini efektif bila peneliti tahu dengan pasti variabel yang akan diukur serta respondennya (Maolani \& Cahyana, 2015). Peneliti memilih angket tertutup untuk memperoleh data terkait pengetahuan, prestasi maupun motivasi mahasiswa, dengan harapan dapat memperoleh data sesuai dengan keadaan yang responden alami. Keseluruhan aspek menggunakan skala likert untuk mempermudah pengolahan data numerik yang sesuai dengan tujuan penelitian. 
Variabel independen pada penelitian ini yaitu wawasan kebangsaan. Variabel dependennya yaitu prestasi mahasiswa, sedangkan variabel moderatornya yaitu motivasi. Analisis data menggunakan (1) statistik deskriptif; (2) pengujian kualitas data yang terdiri dari uji validitas, uji reliabilitas, uji asumsi klasik; dan (3) uji hipotesis.

Maolani \& Cahyana (2015) menyatakan bahwa statistik deskriptif digunakan untuk menganalisis data dengan cara mendeskripsikan atau menggunakan data yang telah terkumpul sebagaimana adanya. Penyajian data dapat dipaparkan melalui tabel, grafik, diagram lingkaran, piktogram, perhitungan modus, median, mean, perhitungan desil, persentil, perhitungan rata-rata, standar deviasi, dan perhitungan persentase. Analisis ini juga dapat dilakukan untuk mencari hubungan antara dua variabel atau lebih.

Uji validitas dapat diukur dengan korelasi product moment (Arikunto, 2013). Uji normalitas data bertujuan untuk mengetahui normal tidaknya sebaran yang digunakan dalam penelitian ini. Uji normalitas pada penelitian ini menggunakan rumus Chi Kuadrat (Arikunto, 2013). Uji heteroskedastisitas dalam penelitian ini bertujuan untuk mengetahui apakah ada penyimpanganpenyimpangan dalam penelitian ini. Uji heteroskedastisitas dilakukan seperti yang diungkapakan oleh Sugiyono (2015) dengan cara uji Glejser menggunakan aplikasi SPSS, dengan ketentuan, apabila nilai signifikasinya $>0.05$ maka tidak terjadi gejala heteroskedasitisas. Uji autokorelasi dalam penelitian ini bertujuan untuk mengetahui pengaruh antara variabel bebas dengan variabel terikat. Uji ini menggunakan uji Durbin-Watson sebagaimana yang dijelaskan oleh Sugiyono (2015).

Hipotesis yang diajukan dalam penelitian ini ialah sebagai berikut. (1) Terdapat pengaruh positif wawasan kebangsaan terhadap prestasi mahasiswa PGSD di Jawa Timur (Ha). (2) Terdapat pengaruh positif motivasi terhadap prestasi mahasiswa PGSD di Jawa Timur (Ha). (3) Terdapat pengaruh positif wawasan kebangsaan terhadap prestasi mahasiswa PGSD di Jawa Timur dengan motivasi sebagai variabel moderatingnya (Ha). Untuk menguji signifikan atau tidaknya pengaruh variabel tersebut, digunakan uji hipotesis menggunakan uji-t.

\section{HASIL DAN PEMBAHASAN}

Uji validitas dapat diukur dengan korelasi Product Moment (Arikunto, 2013). Berdasarkan hasil perhitungan SPSS versi 18, didapatkan hasil bahwa 14 item angket untuk pengambilan data tentang pengetahuan mahasiswa tentang wawasan kebangsaan dinyatakan valid. Keseluruhan item memiliki hasil akhir paling tinggi $r$ sebesar 0,688 dan $r$ terendah sebesar 0,475. Berdasarkan hasil perhitungan tentang item angket untuk mengetahui prestasi mahasiswa, didapatkan hasil bahwa semua item angket telah memenuhi syarat minimal validasi, yaitu sebesar 0,3610. Adapun hasil validitas terendah sebesar 0,395, sementara tertingginya sebesar 0,712. Berdasarkan hasil 
perhitungan, didapatkan data bahwa sebanyak 16 item angket dinyatakan valid, atau diatas 0,3610 . Adapun $r$ hitung terendah sebesar 3,62 dan $r$ hitung tertinggi sebesar 0,707. Berdasarkan hasil tersebut, dapat disimpulkan bahwa item angket tentang motivasi mahasiswa telah valid.

Uji reliabilitas dilakukan dengan cara membandingkan angka alpha cronbach dengan ketentuan nilai cronbach alpha minimal adalah 0,6. Berdasarkan hasil perhitungan SPSS versi 18, didapatkan hasil bahwa item angket tentang wawasan kebangsaan memiliki cronbach's alpha sebesar 0,738. Hal ini menunjukkan bahwa nilai hitung lebih besar dari 0,6. Dengan demikian, bisa dikatakan bahwa item angket wawasan kebangsaan reliabel.

Berdasarkan hasil perhitungan tentang item angket untuk mengetahui prestasi mahasiswa, didapatkan hasil bahwa semua item angket dapat dikatakan reliabel. Adapun hasil penghitungan cronbach's alpha sebesar 0,795. Berdasarkan hasil perhitungan, didapatkan data bahwa besaran cronbach's alpha untuk item angket motivasi sebesar 0,770. Berdasarkan hasil tersebut, dapat disimpulkan bahwa item angket tentang motivasi mahasiswa telah reliabel. Uji normalitas data dapat dilihat pada tampilan data di Gambar 1, yaitu histogram pada masing-masing variabel, yaitu wawasan kebangsaan, prestasi, dan motivasi.

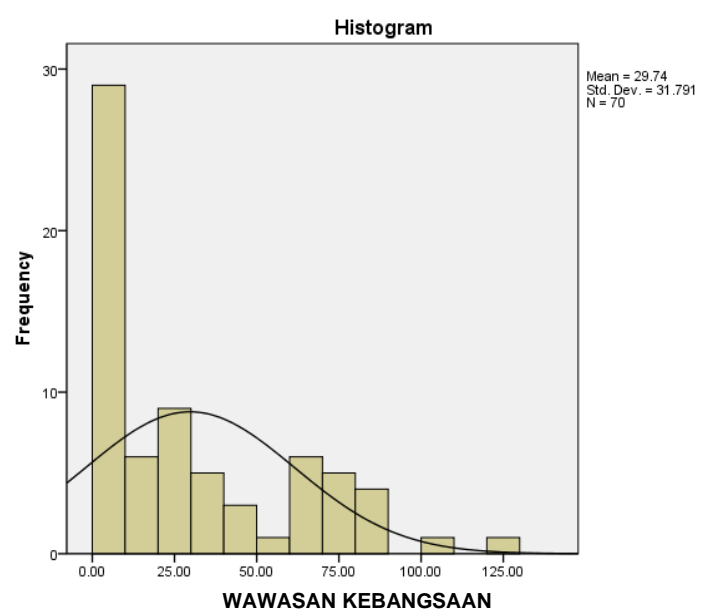

(a)

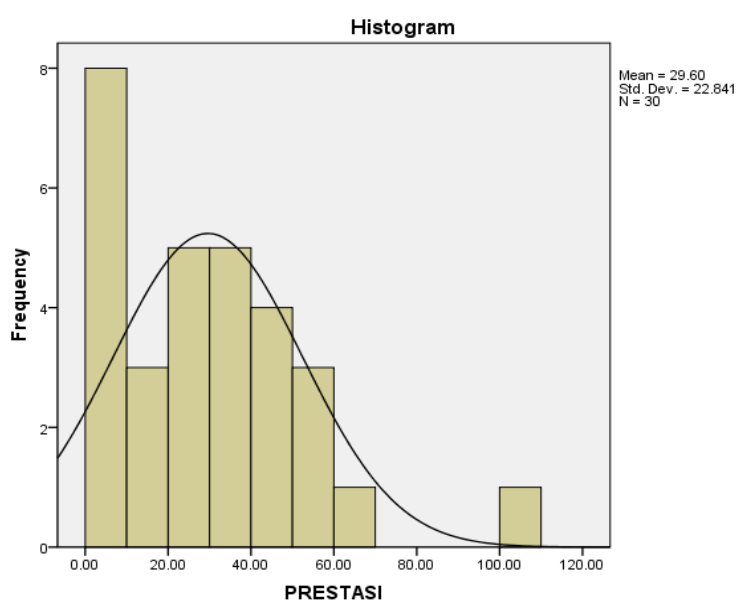

(b)

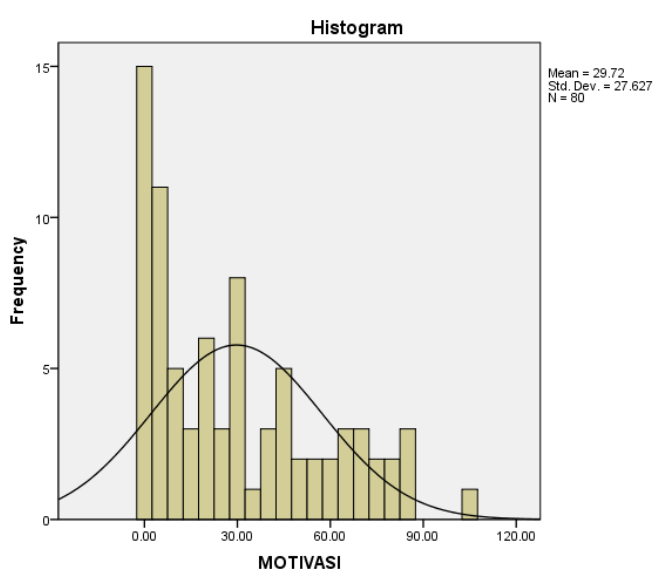

(c) 


\section{Gambar 1. (a) Histogram untuk Variabel Wawasan Kebangsaan, (b) Histogram untuk Variabel Prestasi; dan (c) Histogram untuk Variabel Motivasi.}

Uji heteroskedastisitas dilakukan seperti yang diungkapakan oleh Sugiyono (2015) dengan cara uji Glejser menggunakan aplikasi SPSS, dengan ketentuan apabila nilai signifikasinya $>0.05$ maka tidak terjadi gejala heteroskedasitisas. Untuk melihat hasil uji heteroskedastisitasnya, kita cukup memperhatikan hasil coefficients dan membandingkan nilai signifikansinya. Hasil uji heterodeksitas dapat dilihat pada Tabel 1.

Tabel 1. Hasil Uji Heteroskedastisitas

\begin{tabular}{|c|c|c|c|c|c|c|}
\hline \multicolumn{7}{|c|}{ Coefficients $^{\mathbf{a}}$} \\
\hline & \multirow[t]{2}{*}{ Model } & \multicolumn{2}{|c|}{ Unstandardized Coefficients } & \multirow{2}{*}{$\begin{array}{c}\text { Standardized } \\
\text { Coefficients } \\
\text { Beta }\end{array}$} & \multirow[t]{2}{*}{$\mathrm{t}$} & \multirow[t]{2}{*}{ Sig. } \\
\hline & & $\mathrm{B}$ & Std. Error & & & \\
\hline \multirow[t]{3}{*}{1} & $($ Constant $)$ & 7.653 & 8.181 & & 0.935 & 0.351 \\
\hline & Wawasan Kebangsaan(X1) & -0.132 & 0.096 & -0.120 & -1.369 & 0.173 \\
\hline & Motivasi(X2) & 0.143 & 0.092 & 0.136 & 1.545 & 0.124 \\
\hline
\end{tabular}

a. Dependent Variable: Abs_RES

Berdasarkan data tersebut, dapat diketahui bahwa nilai signifikansi untuk wawasan kebangsaan (X1) dan motivasi (X2) terhadap prestasi mahasiswa (Y) lebih besar dari 0,05. Hal ini menandakan bahwa tidak terjadi gejala heteroskedastisitas sehingga uji regresi yang dilakukan hasilnya bisa dikatakan valid.

Uji hipotesis menggunakan uji-t. Uji-t merupakan salah satu uji hipotesis penelitian dalam analisis regresi linear sederhana maupun analisis regresi linear berganda. Uji-t bertujuan untuk mengetahui apakah variabel bebas/independen $(\mathrm{X})$ secara parsial berpengaruh terhadap variabel terikat/dependen (Y).

\section{Tabel 2. Hasil Uji Hipotesis}

\section{Coefficients $^{a}$}

\begin{tabular}{|c|c|c|c|c|c|c|}
\hline & \multirow[t]{2}{*}{ Model } & \multicolumn{2}{|c|}{ Unstandardized Coefficients } & \multirow{2}{*}{$\begin{array}{c}\begin{array}{c}\text { Standardizeo } \\
\text { Coefficients }\end{array} \\
\text { Beta }\end{array}$} & \multirow[t]{2}{*}{$\mathrm{t}$} & \multirow[t]{2}{*}{ Sig. } \\
\hline & & B & Std. Error & & & \\
\hline \multirow[t]{3}{*}{1} & (Constant) & 7.653 & 8.181 & & 0.935 & 0.351 \\
\hline & Wawasan Kebangsaan(X1) & -0.132 & 0.096 & -0.120 & -1.369 & 0.173 \\
\hline & Motivasi(X2) & 0.143 & 0.092 & 0.136 & 1.545 & 0.124 \\
\hline
\end{tabular}

a. Dependent Variable: Abs_RES 
Berdasarkan Tabel 2, dapat diketahui bahwa nilai signifikasi variabel wawasan kebangsaan (X1) sebesar 0,173. Dengan demikian bisa diketahui bahwa nilai Sig. 0,173 > probabilitias 0,05 sehingga dapat disimpulkan bahwa $\mathrm{H}_{1}$ atau hipotesis pertama ditolak. Artinya, tidak ada pengaruh antara wawasan kebangsaan (X1) terhadap prestasi mahasiswa PGSD (Y). Berdasarkan perbandingan nilai $t_{\text {hitung }}$ dengan nilai $t_{\text {tabel, }}$, dapat diketahui nilai $t_{\text {hitung }}$ variabel wawasan kebangsaan sebesar $-1,369<1.2873$ tabel $(147$ pada taraf 0,01$)$. Hal ini menandakan bahwa hipotesis pertama ditolak berarti tidak ada pengaruh wawasan kebangsaan terhadap prestasi mahasiswa

Pada Tabel 2 juga dapat dilihat bahwa nilai signifikasi variabel motivasi (X2) sebesar 0,124. Dengan demikian bisa diketahui bahwa nilai Sig. 0,124 > probablitias 0,05 sehingga dapat disimpulkan bahwa $\mathrm{H}_{1}$ atau hipotesis pertama ditolak. Artinya, tidak ada pengaruh antara motivasi (X2) terhadap prestasi mahasiswa PGSD (Y). Berdasarkan perbandingan nilai thitung dengan nilai $\mathrm{t}_{\text {tabel}}$, dapat diketahui nilai $\mathrm{t}_{\text {hitung }}$ variabel wawasan kebangsaan sebesar $1.545>1.2872 \mathrm{t}_{\text {tabel }}$ (149 pada taraf 0,01). Hal ini menandakan bahwa hipotesis pertama diterima, berarti ada pengaruh antara motivasi terhadap prestasi mahasiswa.

Untuk menyimpulkan pengaruh motivasi sebagai variabel moderating, maka perlu dihitung regresi pertama dan regresi kedua. Pada regresi pertama, diketahui bahwa R Square nya sebesar 0,016. Sementara itu, pada regresi kedua mengalami kenaikan menjadi sebesar 0.121. dengan melihat hasil di atas, terjadi kenaikan antara hasil regresi pertama dan kedua. Dengan demikian dapat disimpulkan bahwa adanya motivasi (variabel moderating) akan dapat memperkuat hubungan wawasan kebangsaan terhadap prestasi mahasiswa.

\section{Wawasan Kebangsaan terhadap Prestasi Mahasiswa PGSD}

Wawasan kebangsaan merupakan cara pandang bangsa yang terkait erat dengan semangat nasionalisme. Pengaruh kehidupan di era globalisasi saat ini menjadi suatu tantangan tersendiri untuk menumbuhkan wawasan kebangsaan pada generasi muda. Munculnya fenomena karnaval untuk memperkenalkan kolaborasi antara pakaian adat nusantara dengan dunia fashion juga dapat menjadi sarana meningkatkan wawasan kebangsaan (Tampubolon \& Darmawan, 2016). Disamping itu pentingnya wawasan kebnagsaan juga ditunjukkan dengan munculnya wawasan kebangsaan pada tes CPNS serta materi diklat Prajabatan untuk CPNS di Indonesia (Hirnanda, 2015; Affandi \& Lestari, 2019).

Wawasan kebangsaan dan semangat nasionalisme, seperti cinta tanah air, perlu ditanamkan sejak dini. Nilai-nilai tersebut perlu diberikan selama pembelajaran di bangku sekolah, mulai dari sekolah dasar hingga sekolah menengah (Budimansyah, 2010). Sofyan dan Sundawa (2015) memberikan informasi bahwa wawasan kebangsaan dapat ditumbuhkan melalui pembelajaran di perguruan tinggi. Hal ini menunjukkan bahwa pembelajaran sangat terkait dengan tumbuhnya nilai-nilai nasionalisme pada generasi muda. 
Berdasarkan hasil analisis data, dapat diketahui bahwa wawasan kebangsaan tidak memiliki pengaruh terhadap prestasi mahasiswa PGSD (Y). Namun demikian, wawasan mahasiswa tetap perlu digali terus karena wawasan kebangsaan ini sangat memengaruhi keberlangsungan bangsa dan negara. Pernyatan tersebut didukung dengan pengertian wawasan kebangsaan sebagai integritas nasional yang erat kaitannya dengan kerangka berpikir dan mentalitas, yaitu cara pandang kesatuan kebangsaan Indonesia (Hakim, 2002). Hal ini sesuai dengan Sundawa (2017) bahwa wawasan kebangsaan sangat diperlukan oleh mahasiswa sebagai generasi penerus bangsa yang dapat diberikan melalui seluruh mata kuliah yang ada, sehingga dapat mengembangkan karakter mahasiswa berwawasan kebangsaan, khususnya pada mata kuliah rumpun sosial seperti IPS dan PKn.

\section{Motivasi Memengaruhi Hubungan antara Wawasan Kebangsaan terhadap Prestasi Mahasiswa}

Motivasi memiliki peran yang penting dalam pembelajaran. Motivasi berperan dalam kesuksesan aktivitas belajar siswa, yang tentu saja dipengaruhi oleh faktor-faktor baik dalam diri siswa, maupun dari luar dirinya (Oktaviana, 2015; Utami \& Mustadi, 2017; Nuraini \& Laksono, 2019). Lin-Siegler, dkk. (2016) menujukkan bahwa rancangan pembelajaran yang terkait dengan perubahan aktivitas atau sikap siswa dalam belajar akan berpengaruh terhadap motivasi siswa dalam belajar di dalam kelas. Holt (2016) mengemukakan bahwa motivasi individu juga dapat diarahkan untuk hal-hal negatif terkait serangan siber (cyberattacks) yang terkait dengan politik dan ideologi suatu bangsa. Hal ini menunjukkan pentingnya suatu pengetahuan terkait wawasan kebangsaan yang disertai dengan motivasi positif terkait nasionalisme pada generasi muda.

Berdasarkan hasil analisis data, diketahui bahwa motivasi dapat memperkuat hubungan wawasan kebangsaan terhadap prestasi mahasiswa. Hal ini sesuai dengan fungsi motivasi yaitu sebagai pendorong usaha dan pencapaian prestasi, dengan motivasi belajar yang baik akan menunjukkan hasil yang baik untuk mencapai prestasi yang diimpikan (Mardianto, 2012).

Hasil penelitian Nurhidayah (2018) menunjukkan bahwa minat belajar dan dukungan orang tua berpengaruh tinggi pada motivasi belajar mahasiswa. Motivasi mahasiswa akan berpengaruh pada prestasinya, seperti penelitian Siregar (2017) yang menyatakan bahwa terdapat hubungan yang positif antara motivasi akademik dengan prestasi akademik mahasiswa. Hal ini juga mendukung hasil penelitian ini karena setelah dianalisis, motivasi ternyata mampu memperkuat wawasan kebangsaan terhadap prestasi mahasiswa.

Motivasi dapat diartikan sebagai kekuatan atau energi seseorang yang dapat menimbulkan persistensi dan antusiasme untuk melakukan sesuatu dengan cara tertentu sesuai tujuan yang direncanakan, baik yang bersumber dari dalam diri (motivasi intrinsik) maupun dari luar individu (motivasi ekstrinsik), sehingga merupakan suatu alat kejiwaan seseorang (Kompri, 2016). Hasil 
penelitian juga mendukung pernyataan ini karena dengan adanya motivasi, ternyata dapat memengaruhi hubungan antara wawasan kebangsan terhadap prestasi mahasiswa.

\section{SIMPULAN DAN SARAN}

\section{Simpulan}

Hasil penelitian menunjukkan bahwa pengetahuan mahasiswa terkait wawasan kebangsaan tidak memengaruhi prestasi mahasiswa PGSD. Namun hasil berbeda didapatkan ketika diuji tentang motivasi yang memengaruhi hubungan antara wawasan kebangsaan dan prestasi mahasiswa PGSD. Hasil penelitian menunjukkan bahwa adanya motivasi (variabel moderating) akan dapat memperkuat hubungan wawasan kebangsaan terhadap prestasi mahasiswa.

\section{Saran}

Melihat pentingnya peran wawasan kebangsaan dalam membentuk karakter pada mahasiswa, maka nilai ini perlu ditanamkan melalui seluruh mata kuliah yang ada, sehingga dapat mengembangkan karakter mahasiswa berwawasan kebangsaan, khususnya pada mata kuliah rumpun sosial seperti IPS dan PKn. Hal ini sangat diperlukan oleh mahasiswa sebagai generasi penerus bangsa Selain itu, penelitian selanjutnya terkait faktor yang dapat meningkatkan nilainilai karakter nasionalisme juga perlu dilakukan untuk memperkuat internalisasi nilai-nilai tersebut pada generasi muda

\section{DAFTAR RUJUKAN}

Affandi, N. K., \& Lestari, R. (2019). Problematika Seleksi CPNS 2018 dalam Pengangkatan Cpns yang Tidak Memenuhi Passing Grade. Civil Service Journal, 13(1 Juni), 61-70.

Arikunto, S. (2013). Prosedur Penelitian Suatu Pendekatan Praktik. Jakarta: Rineka Cipta.

Budimansyah, D. (2010). Tantangan Globalisasi terhadap Pembinaan Wawasan Kebangsaan dan Cinta Tanah Air di Sekolah. Jurnal Penelitian Pendidikan, 11(1), 8-16.

Dimyati \& Mudjiono. (2010). Belajar dan Pembelajaran. Jakarta: Rineka Cipta.

Hakim, S. A. (2002). Pendidikan Kewarganegaraan. Malang: UM Press.

Hirnanda, D.P. (2015). Evaluasi Penyelenggaraan Pendidikan dan Pelatihan Prajabatan Calon Pegawai Negeri Sipil di Badan Pendidikan dan Pelatihan Provinsi Jawa Timur. Jurnal Mahasiswa Teknologi Pendidikan, 6(1).

Holt, T. J., Kilger, M., Chiang, L., \& Yang, C. S. (2017). Exploring the Correlates of Individual Willingness to Engage in Ideologically Motivated Cyberattacks. Deviant behavior, 38(3), 356-373.

Kompri. (2015). Motivasi Pembelajaran Perspektif Guru dan Siswa. Bandung: PT Remaja Rosdakarya.

Lin-Siegler, X., Dweck, C. S., \& Cohen, G. L. (2016). Instructional Interventions That Motivate Classroom Learning. Journal of Educational Psychology, 108(3), 295.

Mahanani, P. (2019). Pendidikan Kewarganegaraan Sekolah Dasar. Malang: UM Press.

Maolani, R.A., \& Cahyana, U. (2015). Metodologi Penelitian Pendidikan. Jakarta: PT Raja Grafindo Persada. 
Nuraini, F. (2017). Kecerdasan Emosional, Kecerdasan Intelektual dan Kecerdasan Spiritual Terhadap Pemahaman Akuntansi Dasar Dengan Motivasi Sebagai Variabel Moderating. Journal of Accounting Science, 1(2), 93-118.

Nuraini, N. L. S., \& Laksono, W. C. (2019). Motivasi Internal dan Eksternal Siswa Sekolah Dasar pada Pembelajaran Matematika. Sekolah Dasar: Kajian Teori dan Praktik Pendidikan, 28(2), 56-64.

Nurhidayah. (2018). Faktor-faktor yang Memengaruhi Motivasi Belajar Mahasiswa Program Studi PGSD FKIP Universitas Ahmad Dahlan. Jurnal Pendidikan Sekolah Dasar Ahmad Dahlan, l(1), 125-145.

Oktaviana, I. (2015). Pengaruh Lingkungan Sekolah Terhadap Motivasi Belajar Siswa Kelas V Sekolah Dasar di Daerah Binaan I Kecamatan Limpung Kabupaten Batang. Doctoral Disertasi. Semarang: Universitas Negeri Semarang.

Sari, K. (2018). Korelasi Motivasi Mahasiswa dalam Mengikuti Perkuliahan terhadap Perencanaan Karier. Jurnal Fokus Konseling, 4(1), 136- 142. Dari https://doi.org/10.26638/jfk.508.2099.

Siregar, N. (2017). Hubungan Motivasi Berprestasi dengan Prestasi Akademik pada Mahasiswa Fakultas Psikologi Universitas Prima Indonesia. Jurnal Diversita, 3(1), 2580-6793. Dari http://ojs.uma.ac.id/index.php/diversita.

Sudaryono, Gaguk. M., \& Wardani, R. (2013). Pengembangan Instrumen Penelitian Pendidikan. Yogyakarta: Graha Ilmu.

Sugiyono. (2015). Metode Penelitian Kuantitatif, Kualitatif, dan $R \& D$. Bandung: Alfabeta.

Sundawa, D. (2017). Penguatan Karakter Mahasiswa yang Berwawasan Kebangsaan dalam Menghadapi Tantangan Disintegrasi Bangsa. Prosiding Seminar Nasional, 3(1), 202-205. Dari http://semnastafis.unimed.ac.id/wp-content/uploads/2017/11/07.-Dadang-SundawaEdit.pdf.

Sofyan, F.S., \& Sundawa. D. (2015). Hubungan Mata Kuliah Pendidikan Kewarganegaraan dengan Peningkatan Wawasan Kebangsaan dan Semangat Nasionalisme Mahasiswa. Jurnal Pendidikan Ilmu Sosial, 24(2), 185.

Tampubolon, A., \& Darmawan, C. (2016). Fashion Budaya Nasional dalam Konteks Wawasan Kebangsaan: Studi Kasus pada Jember Fashion Carnaval. Journal of Urban Society's Arts, $3(1), 19-26$.

Utami, K. N., \& Mustadi, A. (2017). Pengembangan Perangkat Pembelajaran Tematik Dalam Peningkatan Karakter, Motivasi, dan Prestasi Belajar Siswa Sekolah Dasar. Jurnal Pendidikan Karakter, 7(1). 